\title{
PEMISAHAN JABATAN PEJABAT UMUM DI INDONESIA
}

\author{
Fayakundia Putra Sufi \\ Fakultas Hukum, Universitas Narotama, Surabaya \\ e-mail: koendhie_ps@yahoo.com \\ Rusdianto Sesung \\ Fakultas Hukum, Universitas Narotama, Surabaya \\ e-mail:rusdianto@narotama.ac.id
}

\begin{abstract}
ABSTRAK
Pejabat umum di Indonesia yang bertugas untuk menjamin kepastian hukum bagi masyarakat yang melakukan perbuatan hukum mulai dari jual beli, sewa menyewa, waris, hibah, wasiat dan perbuatan perbuatan keperdataan lainnya. Dalam hal ini notaris sebagai pejabat umum yang diberikan wewenang oleh undang-undang, melalui diundangkannya Undang-Undang No. 30 Tahun 2004 tentang Peraturan Jabatan Notaris. Meskipun dalam UUJN telah jelas mengatur mengenai wewenang jabatan Notaris, namun dalam jabatan pejabat umum notaris bukanlah satu-satunya jabatan yang disandang pejabat umum untuk membuat alat bukti otentik (akta). Dalam pembuatan akta di bidang pertanahan dikerjakan oleh Pejabat Pembuat Akta Tanah, sedangkan untuk membuat Akta risalah lelang dibuat oleh Pejabat Lelang kelas II yang semuanya itu mempunyai dasar aturan dan pertanggung jawaban yang berbeda padahal sebenarnya wewenang tersebut telah ada pada jabatan notaris dan wewenang tersebut telah diatur secara jelas pada Pasal 15 UUJN. Jurnal ini akan menggunakan metode penelitian normatif, akan banyak menggunakan pendekatan konseptual, dan menggunakan pendekatan histori yang mana akan membahas sejarah dari masing-masing jabatan pejabat umum. Dalam menganalisa isu hukum akan menggunakan beberapa teori seperti teori wewenang. Pada akhir jurnal ini dapat kita temukan alasan mengapa jabatan pejabat umum harus dipisah, dan tidak disandang hanya dengan jabatan notaris.
\end{abstract}

Kata Kunci: Pejabat Umum, Pemisahan Jabatan, Notaris.

\begin{abstract}
General public officials in Indonesia who are committed to ensuring legal certainty for people who commit legal acts ranging from sale, lease, heirs, grants, wills and other civil actions. In this case the Notary as a general officer authorized by law, through the enactment of Law No. 30 of 2004 on Notary Public Regulation. Although UUJN has clearly regulated the authority of a Notary position, but in the office of a notary public office it is not the only office held by a public official to create an authentic proof (deed) tool. In the making of deed in the field of land is done by the Land Authorities Act, whereas to make the Auction Brochure Act made by the Class Auction Officer all of which have different rules and responsibilities whereas the actual authority has already existed notary and the authority is regulated clearly in Article 15 of the UUJN. This journal will use normative research methods, will use a lot of conceptual approaches, and use historical approaches which will explain the history of each public official. In analyzing legal issues will use several theories such as the theory of authority. At the end of this journal we can find the reason why the position of public officials should be separated, and not only served by notary office.
\end{abstract}

Keywords: General Office, Department Separation, Notary.

\section{PENDAHULUAN}

Sebagai negara hukum, sebagaimana yang diterangkan dalam Penjelasan Undang-Undang Dasar 1945 (UUD 1945). Maka segala sesuatu yang berhubungan dengan penyelenggaraan negara dan pemerintahan harus berlandaskan dan berdasarkan atas hukum, sebagai tolak ukur suatu perbuatan atau 
tindakan telah sesuai atau tidak dengan ketentuan yang telah berlaku. Di Indonesia wilayah penanganan hukum privat ditangani oleh pejabat umum, berbeda dengan Pejabat Negara dan pejabat Pemerintahan istilah pejabat umum merupakan terjemahan dari istilah Openbare Amtenaren yang terdapat pada Pasal 1 Peraturan Jabatan Notaris (selanjutnya disebut PJN). ${ }^{1}$ Istilah Openbare Amtrnaren yang terdapat pada Pasal 1 Reghlement op het Notaris Ambt in Indonesia (ord. Van jan. 1860) Staatsblad 1860 Nomor 3. Demikian pula istilah Openbare Ambtenaren yang terdapat pada Pasal 1868 BW diterjemahkan Pejabat Umum oleh R. Soebekti dan R. Tjitrosudibio dalam Kitab Undang-Undang Hukum Perdata terjemahan mereka. ${ }^{2}$

Pejabat umum di negara Indonesia secara penyandang jabatannya dapat dibagi menjadi 2, yang dijabat oleh Non Pegawai Negeri Sipil (Non PNS) yaitu Notaris, Pejabat Pembuat Akta Tanah (PPAT), dan Pejabat Lelang kelas II, namun ada pula pejabat umum yang disandang pula oleh PNS, seperti contohnya catatan sipil yang mana tugas catatan sipil juga menerbitkan akta namun tidak lebih dari 1 (satu) atau 2 (dua) pihak di dalamnya, seperti akta kelahiran, pernikahan, perceraian, dan akta kematian. Dan juga pejabat lelang kelas 1, yang mana jabatan ini juga disandang oleh PNS yakni oleh Pejabat Direktorat Keuangan Negara.

Sebagaimana di negara Indonesia yang terjadi saat ini peranan pejabat umum masih terbagi menjadi beberapa jabatan, yakni Notaris yang mana dalam pemangku jabatan ini diatur oleh UndangUndang No. 30 Tahun 2004 tentang Jabatan Notaris sebagaimana telah diubah dengan Undang-Undang No. 2 Tahun 2014 tentang Perubahan Atas UndangUndang No. 30 Tahun 2004 tentang Jabatan Notaris (selanjutnya ditulis UUJN).

PPAT dalam jabatan ini hukum privat yang berada dalam kewenangannya yaitu seputar hukum Agraria, yang mana jabatan ini tunduk pada Peraturan Pemerintah No. 24 Tahun 1997 tentang Pendaftaran Tanah dan Peraturan Pemerintah No. 37 Tahun 1998 tentang Peraturan Jabatan Pejabat Pembuat Akta Tanah. Pertangunggjawaban jabatannya seorang

\footnotetext{
1 Ghansham Anand, Karakteristik Jabatan Notaris di Indonesia, Zifatama Publisher, Sidoarjo, 2014, h. 16.

${ }^{2}$ R. Soebekti dan R. Tjitrosudibio, Kitab Undang-Undang Hukum Perdata, Pradnya Paramita, Jakarta, 1983, h. 475.
}

PPAT adalah kepada Kepala Badan Pertanahan Nasional, sesuai dengan Peraturan Kepala Badan Pertanahan Nasional (Perka BPN) No. 1 Tahun 2006. Sedangkan tugas dan wewenang mengenai produk hukum antara lain, Akta Jual Beli, Tukar Menukar, Akta Pemberian Hak Tanggungan, Surat Kuasa Membebankan Hak Tanggungan, Hibah, Pembagian Hak Bersama.

Pejabat umum lainnya yang ada di Indonesia adalah Pejabat Lelang (selanjutnya disingkat PL). Jabatan ini di indonesia tergolong cukup banyak. Pada jabatan ini masih terbagi lagi menjadi 2, yang mana pembagian ini dibagi sesuai tugas dan wewenang dan siapa yang dapat menyandang jabatan tersebut. Pertama, yakni PL kelas I, pada jabatan ini PL kelas I hanya dapat dijabat oleh PNS Pejabat Direktorat Jendral Kekayaan Negara (DJKN) di Kementerian Keuangan. Kedua, PL kelas II, jabatan ini dapat diberikan kepada Notaris, Penilai, dan Pensiunan PNS DJKN dan masa jabatannya PL kelas II tidak berdasarkan umur pemangku jabatan seperti Notaris dan PPAT yang mana sampai 65 tahun, namun hanya 5 tahun dan dapat diperpanjang.

Kewenangan jabatan notaris sendiri sebenarnya sudah diatur pada Pasal 15 UUJN, yang sebenarnya sudah memuat tugas untuk membuat alat bukti otentik (akta) dalam bidang pertanahan, dan risalah lelang, namun dalam praktiknya seorang yang hanya menyandang jabatan notaris masih belum bisa membuat akta tanah dan risalah lelang. Pada jabatan PPAT dan PL kelas II memang diangkat dari seorang Notaris, yang terlebih dahulu melalui persyaratanpersyaratan layaknya akan menjadi notaris seperti magang dan mengikuti ujian kode etik jabatan, dan lain-lain.

Wolff R.P. menerangkan bahwa kewenangan dapat diperoleh dari keterampilan, ${ }^{3}$ on one influential view, To claim authority is to claim the right to be obeyed There are, of course, authorities that make no such claim. Theoretical authorities, i.e., experts, are not characterized by claims to obedience-they need not even claim a right to be believed. And there are weaker forms of practical authority.

${ }^{3}$ Wolff, R.P., "In Defense of Anarchism”, University of California Press, dalam Jurnal Internasional Stanford Encyclopedia of Philosophy, Stanford University, Berkeley, 1970, h. 23. 
Dari kutipan tersebut dapatlah kita pahami bahwa seperti jabatan pejabat umum dalam memperoleh kewenangan adalah diperoleh bukan hanya dari kepercayaan masyarakat saja namun juga dengan berketerampilan yang baik dan memang telah ahli dalam bidangnya, untuk memberikan pelayanan terhadap masyarakat.

E. Utrecht berpendapat bahwa dia dapat menerima pembagian kekurangan ketetapan kedalam kekurangan yang esensial (inti) dan yang bukan yang esensial. Namun kandungan kekurangan tersebut harus dilihat secara kasuistis yang penting bahwa keputusan administrasi negara adalah pemanfaatan atau kegunaannya doelmatigheid lebih penting dari pada sesuai tidaknya dengan hukum positif rechtsmatigheid. ${ }^{4}$

Pengertian asas kepastian hukum atau rechtmatigeheid diartikan sebagai asas dalam negara hukum yang menggunakan landasan peraturan perundang-undangan, kepatutan, dan keadilan dalam setiap kebijakan penyelenggara negara. Dalam kebijakan tersebut itu harus mempunyai doelmatigheid atau tujuan sesuai dengan bevoegheid atau ruang lingkup kewenangan yang dimilikinya bahkan seharusnya sesuai dengan expertise atau keahlian. $^{5}$

Asas-asas pembentukan peraturan perundangundangan yang baik harus menjadi pedoman dalam proses pembuatan undang-undang mengingat fungsinya yang penting dalam persyaratan kualitas peraturan hukum, sehingga undang-undang yang dihasilkan memiliki efektifitas dalam pencapaian tujuan atau doeltreffendheid, pelaksanaan atau uitvoerbaarheid, dan penegakan hukumnya atau handhaafbaarheid. Proses pembentukan undangundang yang berkelanjutan, harus tunduk pada asasasas pembentukan peraturan perundang-undangan yang baik sebagai asas hukum. ${ }^{6}$

Dengan adanya pemisahan jabatan pejabat umum yang disandang oleh satu orang yang sama seperti yang terjadi saat ini menjadikan adanya ketidak

\footnotetext{
${ }^{4}$ Boedi Djatmiko, "Karakter Hukum Keputusan PTUN", Makalah, Yogyakarta, 2009, diunduh dari di http://sertifikattanah. blogspot.com/2009/09/karakter-hukum-keputusan-ptun.html, h. 8 .

${ }^{5}$ Peter Mahmud Marzuki, Penelitian Hukum, Kencana Prenada Media Group, Jakarta, 2010, h. 82.

${ }^{6}$ Praajudi Atmosudirdjo, Hukum Administrasi Negara, Ghalia Indonesia, Jakarta, 1988, h. 75.
}

efisien dari segi pejabatnya, yang mana pejabat yang sama harus bertanggungjawab kepada banyak instansi, seperti Kementerian Hukum dan Hak Asasi Manusia ketika notaris menjalankan dan membuat akta akta notariil. Kementrian keuangan ketika notaris menjalankan jabatannya sebagai Pejabat Lelang kelas II, kerja sama membuat akta-akta perbankan. Kementerian Agraria, pada instansi ini notaris wajib melaporkan akta-akta yang berkaitan dengan pertanahan ketika menjalankan tugasnya sebagai PPAT, dan masih banyak pihak lain.

Dari pemaparan di atas dijumpai ketidaksesuaian dari beberapa prinsip hukum di atas dengan apa yang telah diatur oleh pemerintah saat ini atau pembuat undang-undang. Dalam artikel ini penulis akan menganalisa mengenai pemisahan jabatan yang telah terjadi pada pejabat umum di Indonesia dengan memakai pisau prinsip-prinsip hukum sebagai tolak ukurnya.

\section{RUMUSAN MASALAH}

Dari latar belakang yang telah kami paparkan mengenai beberapa jabatan yang disandang oleh notaris kami menarik rumusan masalah, yaitu ratio legis pemisahan jabatan pejabat umum di Indonesia dan ratio decidensi jabatan tersebut harus dipisah.

\section{METODE PENELITIAN}

Penelitian ini merupakan suatu penelitian hukum yang normatif dengan pertimbangan bahwa titik tolak penelitian ini yaitu analisis mengenai pemisahan jabatan pejabat umum di Indonesia sebagimana yang terjadi pada saat ini Notaris, PPAT, PL kelas II, serta mengkaji kedudukan adanya pemisahan jabatan tersebut dengan prinsip-prinsip Good Governance. Peter Mahmud Marzuki menyatakan bahwa penelitian hukum merupakan proses untuk menemukan aturan hukum, prinsip-prinsip hukum, maupun doktrin-doktrin hukum guna menjawab isu hukum yang dihadapi. ${ }^{7}$

Pendekatan yang digunakan dalam penelitian hukum ini akan sedikit menggunakan pendekatan perundang-undangan atau statue approach, dan pendekatan konseptual atau concetual approach. Pendekatan konseptual atau conceptual approach yang mana dalam menganalisa rumusan masalah yang telah dipilih kami mencoba menganalisa secara

\footnotetext{
${ }^{7}$ Peter Mahmud Marzuki, Op.Cit., h. 35.
} 
konseptual mulai dari konsep politik hukumnya sehingga muncul aturan pemisahan jabatan pejabat umum tersebut. Dalam menganalisa ratio legis kita perlu memahami pula dari pendekatan sejarah atau historical approach, ${ }^{8}$ apa sebenarnya yang terjadi pada masa itu sehingga suatu aturan itu dirumuskan atau dirancang.

Pendekatan perundang-undangan atau statue approach digunakan karena dalam pembahasan artikel ini akan mengacu pada undang-undang. ${ }^{9}$ Dengan pendekatan ini kami ingin menganalisa dari segala macam peraturan mengenai pejabat umum. Hal ini digunakan sebagai pendekatan dalam menelaah berbagai macam auran pemisahan jabatan pejabat umum di Indonesia.

Pendekatan konseptual atau conceptual approach, pada penelitian ini pendekatan konseptual akan lebih banyak kami digunakan untuk mengkaji dan menganalisis kerangka pikir atau kerangka konseptual maupun landasan teoritis sehingga dapat ditemukan konsep atau teori yang terkandung dalam aturan aturan yang akan kita kaji terkait dengan pemisahan jabatan.

Pendekatan sejarah atau historical approach, digunakan dalam kerangka pelacakan sejarah lembaga hukum dalam hal ini pejabat umum dari waktu ke waktu. ${ }^{10}$ Pendekatan sejarah diperlukan untuk melacak secara historis guna memahami landasan filosofis lahirnya ketentuan atau aturanaturan terkait pemisahan jabatan pejabat umum di Indonesia.

\section{PEMBAHASAN}

\section{Sejarah Pejabat Umum (Sejarah Notaris)}

Lembaga notaris berasal dari Italia Utara pada abad ke 11 atau 12 sebelum Masehi, yang pada saat itu Italia Utara merupakan pusat perdagangan yang sangat berkuasa. Daerah inilah yang merupakan tempat asal dari lembaga notariat yang kemudian dikenal dengan nama Latijnse Notariaat dan karakteristik ataupun ciri-ciri dari lembaga ini yang kemudian tercermin dalam diri notaris saat ini yakni: Diangkat oleh penguasa umum; Untuk kepentingan

\footnotetext{
${ }^{8}$ Johnny Ibrahim, Teori dan Metodologi Penelitian Hukum Normatif, Bayumedia, Malang, 2010, h. 93.

${ }^{9}$ Sunaryati Haryono, Penelitian Hukum di Indonesia Pada Akhir Abad Ke-20, Alumni, Bandung, 1994, h. 139.

${ }^{10}$ Peter Mahmud Marzuki, Op.Cit., h. 126.
}

masyarakat umum dan; Menerima uang jasanya (honorarium) dari masyarakat umum. ${ }^{11}$

Pertama kalinya nama Notarii diberikan kepada orang-orang yang mencatat atau menuliskan pidato yang diucapkan Cato dalam senat Romawi. Kemudian pada abad ke-5 yang diartikan Notarii adalah pejabatpejabat istana yang melakukan berbagai pekerjaan konselarij kaisar yang semata-mata merupakan pekerjaan administratif.

Lembaga notariat yang berasal dari Italia Utara tersebut kemudian berkembang dan meluas sampai ke dataran Eropa melalui Spanyol kemudian ke Amerika Tengah dan Selatan, kecuali Inggris dan Negara Skandinavia dan sampai ke Indonesia pada abad ke-17 melalui Perancis yang saat itu menjajah Belanda. $^{12}$

Pengaturan lembaga notariat sempat mengalami beberapa perubahan, melalui Dekrit Kaisar tertanggal 1 Maret 1811 berlakulah Undang-Undang Kenotariatan Perancis di Belanda. Peraturan buatan Perancis ini (25 Ventose an XI (16 Maret 1803)) sekaligus menjadi peraturan umum pertama yang mengatur kenotariatan di Belanda. Setelah Belanda lepas dari kekuasaan Perancis pada tahun 1813, peraturan buatan Perancis ini tetap dipakai sampai tahun 1842 yakni pada saat Belanda mengeluarkan Undang-Undang tanggal 19 Juli 1842 (Ned. Stbl. No. 20) tentang Jabatan Notaris. Undang-Undang Jabatan Notaris atau Wet op het Notarisambt (Notariswet) pada dasarnya tetap mengacu pada undang-undang buatan Perancis sebelumnya (Ventosewet) dengan penyempurnaan pada beberapa pasal, misalnya tentang penggolongan notaris, dewan pengawas, masa magang, dan proses teknis pembuatan akta. ${ }^{13}$

Undang-undang kenotariatan Belanda hasil "penyempurnaan" dari undang-undang kenotariatan Perancis ini tidak ikut diadopsi ke ranah hukum Indonesia pada saat Belanda menjajah Indonesia. Justru yang berlaku adalah peraturan lama yang dipakai Belanda sebelum dijajah Perancis. Baru pada tahun 1860 , peraturan yang senada dengan peraturan kenotariatan Belanda atau Notariswet berlaku dengan dikeluarkannya Peraturan Jabatan Notaris (selanjutnya disingkat PJN) pada tanggal

${ }^{11}$ G.H.S. Lumbun Tobing, Peraturan Jabatan Notaris, Erlangga, Jakarta, 1996, h. 3.

\footnotetext{
12 Ibid.

${ }^{13}$ Ibid, h. 4.
} 
1 Juli 1860. Sehingga bila dianalisa maka UndangUndang Kenotariatan yang berlaku di Indonesia sekarang dulunya berasal dari peraturan kenotariatan Perancis yang berlaku di Belanda yang kemudian telah disempurnakan. PJN adalah copie dari pasalpasal dalam Notariswet yang berlaku di Belanda. ${ }^{14}$

Keberadaan jabatan notaris pertama kali di Indonesia pada tanggal 27 Agustus 1620 dengan diangkatnya seorang Belanda bernama Melchior Kerchem yang merupakan seorang sekretaris dari College van Schepenen di Jacatra, beberapa bulan setelah Jacatra dijadikan sebagai Ibukota (tanggal 4 Maret 1621 dinamakan Batavia). Kerchem ditugaskan untuk kepentingan publik khususnya berkaitan dengan pendaftaran semua dokumen dan akta yang telah dibuatnya. Awalnya, para notaris adalah pegawai VOC atau Vereenigde Oost-Indische Compagnie sehingga tidak memiliki kebebasan dalam menjalankan tugasnya sebagai pejabat umum yang melayani masyarakat. Baru sesudah tahun 1650 notaris benar-benar diberikan kebebasan dalam menjalankan tugasnya dan melarang para prokureur mencampuri pekerjaan kenotariatan. ${ }^{15}$

Dalam kenyataannya para Notaris pada waktu itu tidak mempunyai kebebasan di dalam menjalankan jabatannya, oleh karena pada masa itu mereka adalah pegawai dari Oost Ind. Compagnie. Bahkan dalam tahun 1632 dikeluarkan plakkaat yang berisi ketentuan bahwa para notaris, sekretaris dan pejabat lainnya dilarang untuk membuat akta-akta transport, jual-beli, surat wasiat dan lain-lain akta, jika tidak mendapat persetujuan terlebih dahulu dari Gubernur Jenderal dan Raden van Indie, dengan ancaman akan kehilangan jabatannya. Dalam prakteknya, ketentuan tersebut tidak dipatuhi oleh pejabat-pejabat yang bersangkutan sehingga akhirnya ketentuan tersebut menjadi tidak terpakai lagi. ${ }^{16}$

Pada jaman itu adanya kebijakan dari pemerintah Hindia Belanda yang menetapkan formasi atau kuota Notaris di setiap daerah. Awalnya Notaris di Jakarta hanya Kerchem, kemudian pada tahun 1650 ditambah menjadi dua orang. Kemudian ditambah lagi menjadi tiga orang pada tahun 1654 , kemudian

\footnotetext{
${ }^{14}$ Ibid

${ }^{15}$ Habib Adjie, Hukum Notaris Indonesia: Tafsir Tematik terhadap UUNo. 30 Tahun 2004 tentang Jabatan Notaris, Refika Aditama, Bandung, 2008, h. 4.

${ }^{16}$ G.H.S. Lumban Tobing, Loc. Cit.
}

ditambah menjadi lima orang pada tahun 1671, dengan ketentuan empat orang harus bertempat tinggal di dalam kota dan satu orang bertempat tinggal di luar kota. Tujuannya agar masing-masing notaris bisa mendapatkan penghasilan yang layak.

Setelah Indonesia merdeka tanggal 17 Agustus 1945, pemerintah tidak segera mengembangkan konsep peraturan baru terkait keberadaan notaris di Indonesia. Keberadaan notaris di Indonesia tetap diakui berdasarkan ketentuan Pasal 2 Aturan Peralihan (AP) UUD 1945, yaitu segala peraturan perundang-undangan yang masih ada tetap berlaku selama belum diadakan yang baru menurut UndangUndang Dasar ini. Berdasarkan ketentuan dalam ketentuan Pasal 2 Aturan Peralihan (AP) UUD 1945 tersebut, Reglement op Het Notaris Arnbt in Nederlands Indie atau Staatsblad 1860 Nomor 3 tetap diberlakukan, sehingga PJN yang berlaku sejak tahun 1860 terus dipakai sebagai satu-satunya undangundang yang mengatur kenotariatan di Indonesia sampai tahun 2004, sedangkan dari berbagai segi PJN sudah tidak sesuai dengan perkembangan jaman. Bila dibandingkan dengan peraturan induknya yakni Notariswet sendiri telah beberapa kali mengalami perubahan untuk menyesuaikan dengan perkembangan hukum dan bisnis di negeri Belanda, sehinga perubahan terhadap PJN adalah sebuah hal yang sudah tidak bisa dihindarkan. ${ }^{17}$

Sejak tahun 1948 kewenangan pengangkatan notaris dilakukan oleh Menteri Kehakiman (sekarang Menteri Hukum dan Hak Asasi Manusia), berdasarkan Peraturan Pemerintah No. 60 Tahun 1948 tanggal 30 Oktober 1948 tentang Lapangan Pekerjaan, Susunan, Pimpinan, dan Tugas Kewajiban Kementerian Kehakiman. Kemudian pada tanggal 13 Nopember 1954 Pemerintah Republik Indonesia mengeluarkan Undang-Undang No. 33 Tahun 1954 tentang Wakil Notaris dan Wakil Notaris Sementara. Dalam Pasal 2 ayat (1) undang-undang tersebut menyatakan bahwa: Kalau notaris tidak ada, Menteri Kehakiman dapat menunjuk seorang yang diwajibkan menjalankan pekerjaan pekerjaan notaris itu; Sambil menunggu ketentuan menteri kehakiman itu, ketua pengadilan dapat menunjuk seorang yang untuk sementara

${ }^{17}$ A.A. Andi Prajitno, Pengetahuan Praktis tentang Apa dan Siapa Notaris di Indonesia? Sesuai UUJN Nomor 2 Tahun 2014, Perwira Media Nusantara, Surabaya, 2015, h. 13-14. (selanjutnya ditulis A.A. Andi Prajitno I) 
diwajibkan menjalankan pekerjaan-pekerjaan notaris yang dimaksud dalam ayat (1). ${ }^{18}$

Sejak masuknya notaris di Indonesia sampai tahun 1822, notaris hanya diatur oleh dua buah reglemen yang agak terperinci, yaitu dari tahun 1625 dan 1765. Reglemen-reglemen tersebut sering mengalami perubahan, karena setiap kali dirasakan ada kebutuhan maka peraturan yang ada diperbaharui, dipertajam atau dinyatakan berlaku kembali ataupun diadakan peraturan tambahannya.

Pada tahun 1860 pemerintah Belanda pada saat itu menganggap telah tiba waktunya untuk sedapat mungkin menyesuaikan peraturan-peraturan mengenai jabatan notaris di Indonesia dengan yang berlaku di negeri Belanda dan karenanya sebagai pengganti dari peraturan-peraturan yang lama diundangkanlah PJN atau Notaris Reglement yang dikenal sekarang ini, pada tanggal 26 Januari 1860 Staatsblad No. 3 yang mulai berlaku pada tanggal 1 Juli 1860. Dengan diundangkannya Notaris Reglement, maka diletakkanlah dasar yang kuat bagi pelembagaan notariat di Indonesia. PJN terdiri dari 66 pasal, di mana 39 pasal mengandung ketentuanketentuan hukuman, disamping banyak sanksi-sanksi untuk membayar penggantian biaya, ganti rugi dan bunga. Ketigapuluh sembilan pasal tersebut terdiri dari 3 pasal mengenai hal-hal yang menyebabkan hilangnya jabatan, 5 pasal tentang pemecatan, 9 pasal tentang pemecatan sementara, dan 22 pasal mengenai denda. ${ }^{19}$

PJN masih bersifat kolonial dan tidak terkodifikasi dengan baik, hingga pengaturan tentang notaris dalam peraturan perundangundangan tersebut di atas dianggap sudah tidak sesuai lagi dengan perkembangan dan kebutuhan hukum masyarakat Indonesia. Oleh karena itu, perlu diadakan pembaharuan dan pengaturan kembali secara menyeluruh dalam satu undang undang yang mengatur tentang jabatan notaris sehingga dapat tercipta suatu unifikasi hukum yang berlaku untuk semua penduduk di seluruh wilayah negara Republik Indonesia. Dalam rangka mewujudkan unifikasi hukum di bidang kenotariatan tersebut, dibentuk UUJN. UUJN terdiri dari 13 Bab dan 92 Pasal, yang diundangkan pada tanggal 6 Oktober 2004 dan mulai berlaku pada tanggal diundangkan. Dalam undang-

\footnotetext{
${ }^{18}$ Habib Adjie I, Op.Cit., h. 5.

${ }^{19}$ A.A. Andi Prajitno I, Op.Cit., h. 17.
}

undang ini diatur secara rinci tentang jabatan umum yang dijabat oleh notaris, sehingga diharapkan bahwa akta otentik yang dibuat oleh atau di hadapan notaris mampu menjamin kepastian, ketertiban, dan perlindungan hukum. ${ }^{20}$

\section{Sejarah Pejabat Umum (Sejarah PPAT)}

Pada masa kolonial segala perbuatan hukum atas tanah baik berupa peralihan hak atau pembebanan hak dilakukan melalui 2 (dua) tahapan, yaitu dihadapan pejabat umum untuk akta perjanjiannya yang berisi perbuatan hukum oleh masing-masing pihak dan selanjutnya dihadapan pejabat balik nama. Dalam rangka memenuhi ketentuan untuk balik nama dan/atau penyerahan secara hukum atau juridische levering, dan perbuatan hukum harus dibuktikan dengan suatu akta dibuat oleh atau hadapan pejabat balik nama atau overschrijving ambtenaar. Karena secara nyata balik nama itu harus dibuktikan pula dengan suatu akta otentik, maka akta yang dibuat di hadapan Pejabat Balik Nama itu erat kaitannya dengan suatu lembaga yang disebut dengan penyerahan secara fisik, secara nyata dan secara wujud atau feitelijke levering; Perlu dipahami perbuatan hukum yang dituangkan dalam akta Balik Nama bukan perbuatan administrasi dan bukan tindakan pendaftaran. ${ }^{21}$

Pejabat Balik Nama atau Overschrijving Ambtenareen bersumber pada Ordonnantie 1834 itu hingga tahun 1947 dijalankan oleh Rechter Commisaris yaitu para Hakim pada Raad van Justitie, karena itu aktanya disebut gerechterlijke acte. Kemudian diikuti dengan pendaftaran di Kantor Pendaftaran Tanah, yang menjadi kewenangan dan tugas-kewajiban serta tanggung jawab Kepala Pendaftaran Tanah waktu itu dijabat oleh Kepala Kadaster dan Kepala Kadaster tidak boleh menolak pendaftaran hipotik. Bahkan di dalam Pasal 1227 BW, penolakan oleh Kepala Pendaftaran Tanah, harus dibuat akta Berita Acara di hadapan Notaris dan/atau Juru Sita. ${ }^{22}$

Pada tahun 1947 dikeluarkan suatu kebijakan baru yaitu berdasarkan Ordonnantie Tahun 1947

\footnotetext{
${ }^{20}$ Ibid., h. 18.

${ }^{21}$ A.A. Andi Prajitno, Pengetahuan Praktis tentang Apa dan Siapa PPAT, Selaras, Malang, 2013, h. 12-13. (selanjutnya ditulis A.A. Andi Prajitno II)

${ }^{22}$ Ibid., h. 14.
} 
No. 55, pejabat yang diberi kewenangan untuk membuat akta "pejabat balik nama" itu adalah Kepala Kadaster, dengan demikian semenjak berlakunya ketentuan tersebut, maka: Kepala Kadaster yang menjabat atau menduduki tugas kewajiban termasuk kewenangannya berfungsi ganda atau dwi fungsi sebagai Pejabat Balik Nama, dan Kepala Pendaftaran Tanah; Kewenangan Rechter Commisaris maupun Residen sebagai Pejabat Balik Nama, semenjak berlakunya Ordonnantie tersebut, berakhir sudah. ${ }^{23}$

Sejak Indonesia merdeka sampai diterbitkannya UUPA obyek Pertanahan di bawah Pengaturan dan Pengawasan Departemen Dalam Negeri, lembaganya disebut Direktorat Jendral Agraria. Pengaturan mengenai bukti perbuatan hukum berupa akta peralihan maupun pembebanan dan pengaturan tentang Pejabat Balik Nama atau Overschrijving Ambtenaar sebagaimana dimaksud dalam ordonansi Balik Nama S. 1834-27 atau Overschrijvings Ordonantie dan perubahan-perubahannya ternyata tidak diikuti oleh UUPA beserta peraturan pelaksanaannya dan pengawasannya di bawah Kementerian Agraria hingga diterbitkannya PP No. 24 Tahun 1997.24

Ketiadaan pengaturan tentang Pejabat Balik Nama atau Overschrijving Ambtenaar ini sesungguhnya merupakan hal yang wajar, yaitu sebagai akibat dari pencabutan Buku ke-Il Kitab Undang-Undang Hukum Perdata, sepanjang yang mengenai bumi, air serta kekayaan alam yang terkandung di dalamnya berikut segala pengecualiannya, sebagaimana terurai di atas. Dengan tiadanya pengaturan mengenai akta penyerahan maupun Pejabat Balik Nama atau Overschrijving Ambtenaar ini menimbulkan persoalan baru mengenai tata cara melakukan penyerahan atau levering hak kebendaan maupun hak kepemilikan secara nyata dalam rangka pengalihan hak atas tanah, khususnya yang terjadi karena jual beli. ${ }^{25}$

Presiden Sukarno selanjutnya mengeluarkan Penetapan Presiden No. 16 Tahun 1948 tentang Pembentukan Panitia Agraria Yogyakarta, Jabatan Menteri Agraria dibentuk berdasarkan Keputusan Presiden tanggal 30 Juli 1953 No. 132 dan dengan Keputusan Presiden No. 55 Tahun 1955 tanggal 29

\footnotetext{
${ }^{23}$ Ibid.

24 Ibid.

${ }^{25}$ Ibid., h. 16.
}

Maret 1955 membentuk Kementerian Agraria dengan Gunawan sebagai menteri pertamanya. ${ }^{26}$

Jawatan Pendaftaran Tanah dengan Keputusan Presiden No. 190 tanggal 1 Juni Tahun 1957 tidak lagi di bawah Kementerian Kehakiman tetapi masuk ke Kementerian Agraria dengan tugas melaksanakan pengukuran, pemetaan dan pembukuan semua tanah di seluruh wilayah Indonesia serta pembukuan hakhak atas tanah dan pencatatan pemindahan hak-hak tersebut. Jawatan Agraria yang selama ini berada di bawah Kementerian Dalam Negeri berdasarkan Undang-Undang No. 7 Tahun 1958 tentang Peralihan Tugas dan Wewenang Agraria yang diundangkan pada tanggal 27 Pebruari 1958 dialihkan menjadi di bawah Kementerian Agraria. ${ }^{27}$

Satu tahun sejak lahirnya UUPA pada tahun 1960 diterbitkan pula peraturan pelaksananya yaitu Peraturan Pemerintah No. 10 Tahun 1961 tentang Pendaftaran Tanah sebagai penunjang tujuan dari diterbitkannya UUPA. Hal tersebut merupakan sejarah atau awal mula lahirnya lembaga PPAT yang dikenal sampai saat ini.

\section{Sejarah Pejabat Umum (Sejarah Pejabat Lelang)}

Lelang dikenal sebagai suatu perjanjian yang termasuk jual beli baik dalam Civil Law maupun dalam Common Law. Herodotus menulis bahwa lelang mulai ada kira-kira tahun 500 SM di Babylon, sekarang berbagai komoditi seperti tembakau, ikan, bunga, surat berharga, dan yang paling penting, lelang digunakan untuk mentransfer aset dari kepemilikan publik ke tangan pemilikan swasta atau perorangan, sebagai fenomena yang mendunia lebih dari dua dekade ini. ${ }^{28}$

Di Indonesia lelang mulai dikenal sejak 1908 dengan diatur dalam peraturan perundang-undangan yaitu dalam Vendu Reglement (Staatsblad 1908 No. 189 diubah dengan Staatsblad 1940 No. 56). Berdasarkan Pasal II Aturan Peralihan UUD 1945 sampai saat ini Vendu Reglement ini masih tetap

${ }^{26}$ Ibid.

27 Tjahjo Arianto, "Dinamika Lembaga Pertanahan", Makalah, disampaikan pada seminar "Pendalaman Hukum Pertanahan dalam Rangka Persiapan Ujian Pejabat Pembuat Akta Tanah 2017" di Universitas Narotama Surabaya, 24-25 Oktober 2016, h. 3-5.

28 Purnama T. Sianturi, Perlindungan Hukum terhadap Pembeli Barang Jaminan Tidak Bergerak Melalui Lelang, Mandar Maju, Bandung, 2013, h. 1. 
dipergunakan sebagai dasar hukum lelang. Sesuai dengan perkembangan, demi untuk mengefektifkan serta mengaktualkan pelaksanaan lelang yang telah diatur dalam Peraturan Lelang, maka diterbitkan berbagai Keputusan Menteri Keuangan maupun Keputusan Dirjen Piutang dan Lelang Negara.

Dalam pelaksanaan lelang yang memimpin adalah seorang PL. Lelang harus dilaksanakan dihadapan PL. Kesepakatan harga dalam lelang baru terbentuk pada saat PL untuk kepentingan penjual menunjuk penawar yang tertinggi dan mencapai harga limit sebagai pembeli lelang. Jadi jual beli dalam lelang tidak murni antara penjual dan pembeli, namun terdapat intervensi PL.

Dalam lelang, PL tidak hanya menyaksikan lelang tetapi justru menyelenggarakan penjualan itu sendiri dan juga membuat akta otentik. Risalah Lelang yang merupakan produk hukum PL statusnya sama dengan akta otentik karena memenuhi syaratsyarat sebagai suatu akta otentik seperti yang diatur dalam Pasal 1868 BW.

Dalam analisa menggunakan pendekatan histori di atas, dapat kita ketahui bahwa jabatan pejabat umum yang masuk ke Indonesia telah terpisah-pisah jabatan, waewenang dan pejabat penyandangnya juga berbeda, namun satu pejabat hanya menjabat 1 jabatan saja, sedangkan yang terjadi di Indonesia saat ini semua jabatan tersebut disandang oleh 1 orang pejabat.

\section{Prinsip Hukum yang Melandasi Pemisahan Jabatan Pejabat Umum di Indonesia}

Penyelenggaraan pemerintahan yang baik haruslah selalu berpedoman pada asas atau prinsip umum penyelenggaraan pemerintahan, karena wilayah Negara Republik Indonesia sangat luas serta penduduk beragam sehingga pemerintahan yang baik dilaksanakan secara seragam untuk wilayah Negara Republik Indonesia. Asas-asas pemerintahan yang baik merupakan sendi dalam mewujudkan pemerintah yang baik negara Indonesia berdasarkan atas hukum, oleh karena itu setiap tindakan penyelenggaraan pemerintahan berdasarkan atau mempedomani peraturan perundangan yang berlaku atau segala tindakan pemerintah harus dapat dipertanggungjawabkan secara hukum. Prinsip dari asas ini dalam rumusan peraturan yang diwujudkan dari cita-cita hukum.
Konsep hukum lain dari negara berdasarkan atas hukum adalah adanya jaminan penegakan hukum dan tercapainya cita-cita hukum seperti yang telah disebutkan di atas. Dalam penegakan hukum ada 3 (tiga) unsur yang selalu harus mendapat perhatian, yaitu keadilan, kemanfaatan atau hasil guna, dan kepastian hukum. Agar ketiga unsur tersebut dapat tercapai maka segala perbuatan hukum pemerintah harus memiliki keabsahan. Dasar Keabsahan Perbuatan Hukum Pemerintahan tersebut antara lain: Sah secara/berdasar hukum atau Rechtmatigheid; Sah secara/berdasar undang-undang atau Wetmatigheid; Sah secara/berdasar tujuan yang efektif dan efisien atau Doelmatigheid en doeltraffenheid; Asas kebebasan bertindak dari penguasa/pemerintah atau Discretie. $^{29}$

Ruang lingkup keabsahan secara keseluruhan meliputi: wewenang, prosedur; dan Substansi. Pada suatu tindakan pemerintah keputusan pemerintahan maupun administrasi tidak boleh melanggar hukum atau onrechtmatige overheidsdaad. ${ }^{30}$ Selain itu pertimbangan manfaat dan tujuan pun harus diperhatikan.

E. Utrecht berpendapat, bahwa dia dapat menerima pembagian kekurangan ketetapan kedalam kekurangan yang esensial (inti) dan yang bukan yang esensial. Namun kandungan kekurangan tersebut harus dilihat secara kasuistis yang penting bahwa keputusan administrasi negara adalah pemanfaatan atau kegunaannya doelmatigheid lebih penting dari pada sesuai tidaknya dengan hukum positif rechtsmatigheid. ${ }^{31}$

Pengertian asas kepastian hukum atau rechtmatigeheid diartikan sebagai asas dalam negara hukum yang menggunakan landasan peraturan perundang-undangan, kepatutan, dan keadilan dalam setiap kebijakan penyelenggara negara. Dalam kebijakan tersebut itu harus mempunyai doelmatigheid atau tujuan sesuai dengan bevoegheid

${ }^{29}$ Asep Warlan Yusuf, "Asas-Asas Hukum Administrasi dan Perkembangannya", Makalah, diunduh dari http://www.pkh. komisiyudisial.go.id/id/files/Materi/TUN01/TUN01_Warlan_ Prinsip .pdf, h. 59.

${ }^{30}$ Prajudi Atmosudirdjo, Hukum Administrasi Negara, Jakarta, Ghalia Indonesia, 1988, h. 87.

${ }^{31}$ Boedi Djatmiko, "Karakter Hukum Keputusan PTUN", Makalah, Yogyakarta, 2009, diunduh dari di http://sertifikattanah. blogspot.com/2009/09/karakter-hukum-keputusan-ptun.html, h. 8 . 
atau ruang lingkup kewenangan yang dimilikinya bahkan seharusnya sesuai dengan expertise atau keahlian. ${ }^{32}$

Kebijakan pemerintah harus bermanfaat bagi maupun bagi masyarakat. Masyarakat dalam hal ini berkepentingan, karena masyarakat menginginkan adanya keseimbangan tatanan dalam masyarakat. Dengan adanya permasalahan yang lahir dari suatu kebijakan keseimbangan tatanan di dalam masyarakat itu terganggu, dan keseimbangan yang terganggu itu harus dipulihkan kembali. ${ }^{33}$

Asas-asas pembentukan peraturan perundangundangan yang baik harus menjadi pedoman dalam proses pembuatan undang-undang mengingat fungsinya yang penting dalam persyaratan kualitas peraturan hukum, sehingga undang-undang yang dihasilkan memiliki efektifitas dalam pencapaian tujuan atau doeltreffendheid, pelaksanaan atau uitvoerbaarheid, dan penegakan hukumnya atau handhaafbaarheid. Proses pembentukan undangundang yang berkelanjutan, harus tunduk pada asasasas pembentukan peraturan perundang-undangan yang baik sebagai asas hukum. ${ }^{34}$

Dari uraian sebagaimana telah disebutkan di atas, terlihat bahwa prinsip efisiensi dan efektifitas harus melekat pada setiap peraturan maupun kebijakan yang dilahirkan oleh pemerintah. Efisiensi pelayanan adalah perbandingan terbaik anatara input dan output pelayanan. Secara ideal, pelayanan akan efisien apabila birokrasi pelayanan dapat menyediakan input pelayanan, seperti biaya dan waktu pelayanan yang meringankan masyarakat pengguna jasa. Demikian pula pada sisi output pelayanan, birokrasi secara ideal harus dapat memberikan produk pelayanan yang berkualitas, terutama dari aspek biaya dan waktu pelayanan. Efisiensi pada sisi input dipergunakan untuk melihat seberapa jauh kemudahan askses publik terhadap sistim pelayanan yang ditawarkan. ${ }^{35}$ Menurut pendapat Prajudi Atmosudirdja, asas efisiensi adalah sasaran wajib dikejar seoptimal mungkin dengan kehematan biaya dengan pencapaian produktivitas tinggi. Sedangkan efektivitas adalah kegiatan harus

\footnotetext{
${ }^{32}$ Peter Mahmud Marzuki, Op.Cit., h. 82.

${ }^{33}$ Sudikno Mertokusumo, Bab-Bab tentang Penemuan Hukum, Citra Aditya Bakti, Bandung, 1993, h. 92.

${ }^{34}$ Praajudi Atmosudirdjo, Op.Cit., h. 75.

${ }^{35}$ Agus Dwiyanto, dkk., Reformasi Birokrasi Publik di Indonesia, Gadjahmada University Press, Yogyakarta, 2008, h. 76.
}

mengenai sasaran atau tujuan yang telah ditetapkan atau direncanakan. ${ }^{36}$

Mengenai prinsip efektifivitas, prinsip ini telah banyak dikemukakan oleh para ahli organisasi maupun manajemen dan memiliki makna yang berbeda tergantung kepada kerangka acuan yang dipergunakan. Efektifitas memiliki peranan penting dalam pencapaian tujuan-tujuan dan efektivitas adalah kunci dari kesuksesan suatu organisasi.

Istilah efektivitas itu sendiri sangat bervariatif di mana penjelasannya dapat menyangkut berbagai dimensi yang memusatkan perhatian kepada berbagai kriteria evaluasi. Selanjutnya pengukurannya relatif beraneka ragam di mana kriteria yang berbeda dilakukan secara serempak. Efektivitas adalah ukuran berhasil tidaknya pencapaian tujuan organisasi. Apabila suatu organisasi berhasil mencapai tujuannya, maka organisasi tersebut telah berjalan dengan efektif.

Georgopoulos dan Tannenbaum mengemukakan bahwa efektivitas organisasi adalah tingkat sejauh mana suatu organisasi yang merupakan sistem sosial, dengan segala sumber daya dan sarana tertentu yang tersedia memenuhi tujuan-tujuannya tanpa pemborosan, dan dengan menghindari ketegangan yang tidak perlu di antara anggota-anggotanya. Dari pengertian tersebut dapat dikatakan bahwa efektivitas sangat tergantung kepada faktor eksternal dan internal organisasi. ${ }^{37}$

Adanya prinsip efisiensi dan efektifitas tersebut di atas melandasi pemisahan jabatan Pejabat Umum yang ada di Indonesia. Pemisahan tersebut membagi Pejabat Umum di Indonesia menjadi 3 bidang yaitu Notaris, PPAT dan PL. Tujuan dari adanya pemisahan jabatan Pejabat Umum di Indonesia apabila dilihat dari prinsip efektivitas maka adanya pemisahan tersebut bertujuan untuk menjamin suatu kepastian hukum dari produk yang dihasilkan oleh Pejabat Umum tersebut. Pemisahan tersebut menghasilkan pejabat umum yang memiliki kekhususan terkait produknya, misalnya untuk urusan yang berkaitan dengan peralihan dan pembebanan hak atas tanah maka kepastian hukum dapat tercapai apabila pejabat yang membuat aktanya, dalam hal ini adalah PPAT mampu bekerja secara profesional dan paham akan

\footnotetext{
${ }^{36}$ Prajudi Atmosudirdjo, Op.Cit., h. 79-80.

${ }^{37}$ Georgopoulos dan Tannenbaum dalam Richard M. Steers, Efektivitas Organisasi, Erlangga, Jakarta, 1985, h. 60.
} 
hukum yang berlaku dalam lingkup pertanahan. Untuk urusan lelang maka pejabat yang memiliki kualifikasi keahlian khusus tersebut ada pada pejabat lelang sedangkan untuk pembuatan akta yang tidak dikhususkan pembuatannya kepada PPAT atau PL maka menjadi kewenangan notaris untuk membuat aktanya.

Selanjutnya mengenai prinsip efisiensi, bahwa pemisahan jabatan Pejabat Umum di Indonesia bertujuan untuk mempermudah masyarakat memperoleh kepastian hukum atas segala perbuatan hukum yang dilakukannya karena Pejabat Umum yang dituju untuk mengkonstantir perbuatan hukum yang telah atau akan dilakukan adalah Pejabat Umum yang telah kompeten dan memiliki kekhususan di bidangnya tersebut.

\section{PENUTUP}

\section{Kesimpulan}

Jabatan Pejabat Umum di Indonesia saat ini dibagi menjadi Notaris, PPAT, dan PL yang mana ke semua jabatan itu disandang oleh 1 (satu) orang pejabat saja. Pemisahan jabatan Pejabat Umum di Indonesia berkaitan dengan prinsip efektivitas dan prinsip efisiensi sebagai berikut:

Pertama, Prinsip Efektifitas, prinsip ini mengedepankan kemampuan untuk menghasilkan hasil sesuai dengan keinginan karena sesuatu yang efektif maka dapat memberikan hasil sesuai dengan yang diharapkan. Pemisahan tersebut menghasilkan pejabat umum yang memiliki kekhususan terkait produknya. Pemisahan jabatan Pejabat Umum diharapkan mampu menjamin suatu kepastian hukum dari produk yang dihasilkan oleh Pejabat Umum tersebut baik pada Notaris, PPAT maupun PL.

Kedua, Prinsip Efisiensi, prinsip ini mengedepankan pemberian pelayanan secara mudah dan sederhana namun memiliki ketepatan guna khususnya dalam hal kepastian hukum. Pemisahan jabatan Pejabat Umum di Indonesia bertujuan untuk mempermudah masyarakat memperoleh kepastian hukum atas segala perbuatan hukum yang dilakukannya karena Pejabat Umum yang dituju untuk mengkonstantir perbuatan hukum yang telah atau akan dilakukan adalah Pejabat Umum yang telah kompeten dan memiliki kekhususan di bidangnya tersebut.
Adapun saran yang dapat kami berikan efektivitas dan efisiensi pemisahan jabatan pejabat umum di Indonesia hanya berlaku pada masyarakat pengguna jasa Pejabat Umum tetapi menjadi tidak efektif dan efisien bagi Pejabat Umum karena memberikan batasan kewenangan dalam pelaksanaan tugas jabatan Pejabat Umum khususnya Notaris. Penerapan Pasal 15 UUJN harus dilakukan agar pejabat juga merasakan efektifitas dan efisien.

\section{Rekomendasi}

Pemisahan jabatan Pejabat Umum yang ada di Indonesia adalah salah bentuk peninggalan jaman kolonial yang saat ini sudah tidak lagi relevan dengan perkembangan jaman. Oleh karena itu notaris diharapkan menjadi satu-satunya pejabat umum yang kewenangannya juga meliputi kewenangan PPAT dan PL kelas II.

\section{DAFTAR PUSTAKA}

\section{Peraturan Perundang-undangan:}

Undang-Undang Dasar Negara Republik Indonesia Tahun 1945.

Undang-Undang Nomor 30 Tahun 2004 tentang Jabatan Notaris.

Undang-Undang Nomor 2 Tahun 2014 tentang Perubahan Atas Undang-Undang Nomor 30 Tahun 2004 tentang Jabatan Notaris.

\section{Buku:}

Adjie, Habib, 2008, Hukum Notaris Indonesia: Tafsir Tematik terhadap UU No. 30 Tahun 2004 tentang Jabatan Notaris, Bandung: Refika Aditama.

Anand, Ghansham, 2014, Karakteristik Jabatan Notaris di Indonesia, Sidoarjo: Zifatama Publisher.

Atmosudirdjo, Prajudi, 1988, Hukum Administrasi Negara, Jakarta: Ghalia Indonesia.

Dwiyanto, Agus dkk., 2008, Reformasi Birokrasi

Publik di Indonesia, Yogyakarta: Gadjahmada University Press.

Georgopoulos dan Tannenbaum dalam Richard M.

Steers, 1985, Efektivitas Organisasi, Jakarta: Erlangga.

Haryono, Sunaryati, 1994, Penelitian Hukum di Indonesia Pada Akhir Abad Ke-20, Bandung:

Alumni. 
Ibrahim, Johnny, 2010, Teori dan Metodologi Penelitian Hukum Normatif, Malang: Bayumedia.

Marzuki, Peter Mahmud, 2010, Penelitian Hukum, Jakarta: Kencana Prenada Media Group.

Mertokusumo, Sudikno, 1993, Bab-Bab tentang Penemuan Hukum, Bandung, Citra Aditya Bakti.

Prajitno, A.A. Andi, 2013, Pengetahuan Praktis tentang Apa dan Siapa PPAT, Malang: Selaras. , 2015, Pengetahuan Praktis tentang Apa dan Siapa Notaris di Indonesia? Sesuai UUJN Nomor 2 Tahun 2014, Surabaya: Perwira Media Nusantara.

Sianturi, Purnama T., 2013, Perlindungan Hukum terhadap Pembeli Barang Jaminan Tidak Bergerak Melalui Lelang, Bandung: Mandar Maju.

Soebekti, R. dan R. Tjitrosudibio, 1983, Kitab Undang-Undang Hukum Perdata, Jakarta: Pradnya Paramita.

Tobing, G.H.S. Lumbun 1996, Peraturan Jabatan Notaris, Jakarta: Erlangga.

\section{Jurnal:}

Wolff, R.P., "In Defense of Anarchism”, University of California Press dalam Jurnal Internasional Stanford Encyclopedia of Philosophy, Stanford University, Berkeley, 1970.

\section{Makalah/Website:}

Arianto, Tjahjo "Dinamika Lembaga Pertanahan", Makalah, disampaikan pada seminar "Pendalaman Hukum Pertanahan dalam Rangka Persiapan Ujian Pejabat Pembuat Akta Tanah 2017" di Universitas Narotama Surabaya, 2425 Oktober 2016.

Djatmiko, Boedi 2009, "Karakter Hukum Keputusan PTUN", Makalah, Yogyakarta, 2009, diunduh dari di http://sertifikattanah.blogspot. com/2009/09/karakter-hukum-keputusan-ptun. $\mathrm{html}$.

Yusuf, Asep Warlan, “Asas-Asas Hukum Administrasi dan Perkembangannya", Makalah, diunduh dari http://www.pkh.komisiyudisial.go.id/id/files/ Materi/TUN01/TUN01_Warlan_Prinsip.pd. 